\title{
Cancer and infertility: psychosocial aspects in young women undergoing ovarian tissue cryopreservation
}

\begin{abstract}
Objectives: The main objective of this study is to analyze the psychosocial impact that causes in young women with cancer, the possible loss of their fertility caused by the treatment of their disease, and to analyse their attitudes toward the intervention of extraction and ovarian tissue cryopreservation which is submitted to preserve their fertility, and identify predictors of greater emotional distress.
\end{abstract}

Methods: This study was conducted with a sample of 116 women newly diagnosed with cancer who were to receive gonadotoxic treatments. They were interviewed and completed a series of instruments (BSI-18, EMASP, COPE).

Results: The level of concern about their possible loss of fertility was high (8.06 out of 10) but undergoing OTC relieved their concern to $97 \%$ of the sample. Most of them preserved their fertility for having children and for not suffering an early menopause. Generally it is the oncologist who informs on this effect. The levels of emotional distress were low. The social support perceived was high and the coping strategies most commonly employed were Cognitive Coping, Search of Support and Active Coping. An increased use of the strategies search of support and religion accompanied to a low use of cognitive strategies and less support perceived will increase the levels of emotional distress.

Conclusions: The possible loss of fertility concerns young women newly diagnosed with cancer. However the level of emotional distress experienced is not clinically significant. Having cryopreserved ovarian tissue alleviates the level of concern.

Keywords: cancer, fertility, preservation, young women, psychosocial aspects, distress, oncofertility
Volume 4 Issue I - 2020

\section{Cristina Saéz-Mansilla, Estrella Durá}

Equipo de Preservación de la Fertilidad, Hospital Universitari i

Politècnic La Fe de Valencia, Spain

Correspondence: Cristina Saéz-Mansilla, Equipo de Preservación de la Fertilidad, Hospital Universitari i Politècnic La Fe de Valencia, Hospital Universitario y Politécnico La Fe, Valencia, Spain, Email cristsamn@hotmail.com

Received: December 31, 2019 | Published: January 24, 2020
Abbreviations: OTC, ovarian tissue cryopreservation; COPE, cognitive coping; EMASP, equation were global social support

\section{Introduction}

Cancer affects increasingly young women who are still in reproductive age, but the advancement in treatments have improved the rates of survival among younger people. ${ }^{1}$ However, these treatments can cause significant side effects; one of the common side effects is the premature ovarian failure and infertility. ${ }^{2}$ This fact, together with the delay in the age at which women become mothers, implies that a significant proportion of cancer survivors do not have children and want them, but they can face serious difficulties to achieve a pregnancy. In general, psychological distress generated by infertility in women has been widely documented in literature. In fact, those who have fertility problems often experience it as an emotionally painful experience and as a stressful situation. ${ }^{3,4,5}$ Even more, some studies have shown that women with infertility have significantly higher levels of depression and twice the prevalence of depressive symptoms than fertil women. ${ }^{6,7}$ But when the cancer is the cause of reproductive problems, emotional reactions may be more intense, given that the problem is compounded by the threat of the disease.

Although this is a relatively new area of study, there are already some publications focusing in this issue. Most results agree that the loss of fertility as a result of cancer treatment has important psychosocial implications in young people. ${ }^{9-20}$ In fact, fertility problems derived from cancer treatments are among the main concerns of young cancer survivors. ${ }^{14,17,18,21,22,23}$ Moreover the fact that the number of young cancer survivors is increasing, appeals to the need to understand and analyze the main psychosocial factors surrounding this issue.
On the other hand, recently, some strategies have been developed in order to preserve reproductive function in women with cancer, like ovum cryopreservation, cyopreservation of embryos or ovarian tissue cryopreservation (OTC). ${ }^{24-35}$ However, there have been few studies from a psychological perspective. In this context, this work analyses the psychosocial repercussions caused by the possible loss of fertility associated with cancer treatment in a sample of young women recently diagnosed with cancer who are going to receive Ovarian Tissue Cryopreservation (OTC). Most studies in this topic have been conducted with cancer survivors, ${ }^{10-23}$ therefore we considered more suitable to work on a sample of women recently diagnosed with cancer. Our study raises two specific objectives:

I. To analyze the information women have received about the possible effects of the cancer treatment on their reproductive capacity, their desires and attitudes towards motherhood, and their motivation and attitudes towards the intervention of extraction and cryopreservation of ovarian tissue they are going to receive.

II. To evaluate various psychological variables relevant in this context and the relationships between them, specifically, emotional distress, coping strategies and social support. Both coping strategies and social support have been confirmed in the Psycho-oncology literature as significant predictors of emotional distress and quality of life of cancer patients ${ }^{36-40}$ so presumably also have an important role in the context of the Onco-fertility; the few studies published to date show evidence in this sense. ${ }^{10}$ Moreover, in the field of human reproduction, both variables have also been related with the emotional distress associated with infertility in the general population..$^{41-44}$ 


\section{Methodology \\ Design and procedure}

This study was conducted with patients from the Hospital Peset of Valencia and from the Hospital La Fe of Valencia in Spain. Both are pioneer centres in applying protocols of extraction and cryopreservation of ovarian tissue in Spain, in order to preserve fertility. Women of reproductive age and adults ( $\geq 18$ years old), newly diagnosed with cancer who were to receive gonadotoxic treatment and were to undergo ovarian tissue cryopreservation (OTC) to preserve their fertility was the sample of this study. All those cancer patients who attended the Hospital Peset to undergo that intervention between May 2007 and September 2010 and those who attended between January 2011 and September 2012 to the Hospital La Fe with the same purpose were the initial sample. Immediately before or after undergoing OTC, the psychologist responsible for the research invited them to participate voluntarily in the study, explaining the general objectives of the study. Those who agreed to participate in the study filled out the written informed consent. Women were identified only with a study number; the list pairing study number and names was kept confidential and destroyed after completion of data collection.

\section{Assessment}

A trained psychologist conducted a semi-structured interview which assessed demographic data, the degree of concern about the effects of treatment on their reproductive capacity, the information received, attitudes toward motherhood and motivations and attitudes towards OTC. This interview was developed specifically for this study using as reference the instrument created by L. Schover and employed in several researches. ${ }^{8,45,46}$ Several instruments for evaluating psychological variables relevant in this context were also administrated: the BSI-18 (Brief Symptoms Inventory 18 Test) ${ }^{47}$ assessing psychological distress by 18 items that provide a global score of emotional distress $(\alpha=0.88)^{1}$ and three subscales which are depression $(\alpha=.73)^{*}$, anxiety $(\alpha=.76)^{*}$ and somatization $(\alpha=0.76)^{*}$; the EMASP (Escala Multidimensional de Apoyo Social Percibido) ${ }^{48}$ which assesses through 12 items the global social support perceived $(\alpha=.76)^{*}$ and social support from the family $(\alpha=.80)^{*}$, from the friends $(\alpha=.82)^{*}$ and from relevant people $(\alpha=.90)^{*}$ and the COPE (COPE Inventory $)^{49}$ to indentify the type of coping strategies employed. The subscales of this instrument did no got satisfactory reliability indices in our sample so we proceeded to factorize the instrument and the new defined subscales were considered for this study: active coping $(\alpha=.85)^{2^{*}}$, search of support $(\alpha=.80)^{*}$, cognitive coping $(\alpha=.76)^{*}$, religion $(\alpha=.85)^{*}$, humor $(\alpha=.85)^{*}$ and alcohol or drugs $(\alpha=.90)^{*}(\operatorname{citar}$ mi tesis).

\section{Sample}

Finally the sample was composed of 116 women of the 122 who were initially invited to participate, between 18 and 40 years old (average age 30.55) diagnosed with different type of cancer (Table 1). $56 \%(\mathrm{~N}=65)$ of the sample was married or in a stable relationship, $41 \%(\mathrm{~N}=47)$ were single and $3 \%(\mathrm{~N}=4)$ were separated or divorced. $97 \%(\mathrm{~N}=112)$ of the sample were Spanish and 3\% $(\mathrm{N}=4)$ of other nationalities (Portuguese, Bulgarian, Peruvian and British). The educational level of the sample was medium-high and $53 \%(\mathrm{~N}=61)$ had universities studies, $37 \%(\mathrm{~N}=43)$ had secondary or high school

'Internal consistency obtained by the scale in the study sample. studies and $10 \%(\mathrm{~N}=12)$ had primary education. $88 \%(\mathrm{~N}=102)$ of the sample had no biological children while $12 \%(\mathrm{~N}=14)$ had at least one biological child. Clinical and sociodemographic data of the sample are shown in Table 1.

Table I Distribution of the sample by clinical and sociodemographic characteristics $(\mathrm{N}=116)$

\begin{tabular}{|c|c|c|}
\hline Type of cancer & $\mathbf{N}$ & $\%$ \\
\hline Breast Cancer & 78 & 67 \\
\hline Hodgking lymphoma & 22 & 19 \\
\hline Non Hodgking lymphoma & 5 & 4 \\
\hline Bowel cancer & 2 & 2 \\
\hline Osteosacroma & 2 & 2 \\
\hline Ovarian tumor & 1 & I \\
\hline Adrenal cancer & I & I \\
\hline Leukemia & I & I \\
\hline Others & 4 & 3 \\
\hline \multirow[t]{2}{*}{ Age } & Range & Mean \\
\hline & 18- 40 & $30.55(S D=5.22)$ \\
\hline Marital status & $\mathbf{N}$ & $\%$ \\
\hline Married/ stable couple & 65 & 56 \\
\hline Single & 47 & 41 \\
\hline Separated/ divorced & 4 & 3 \\
\hline Nationality & $\mathbf{N}$ & $\%$ \\
\hline Spanish & 112 & 97 \\
\hline Other countries & 4 & 3 \\
\hline Educational level & $\mathbf{N}$ & 5 \\
\hline Universities studies & 61 & 53 \\
\hline Secondary/ high school & 43 & 37 \\
\hline Primary education & 12 & 10 \\
\hline Employment situation & $\mathbf{N}$ & $\%$ \\
\hline Working & 93 & 80 \\
\hline Studying & 13 & 11 \\
\hline Unemployed & 6 & 5 \\
\hline Housekeeper & I & I \\
\hline Others & 3 & 3 \\
\hline Children & $\mathbf{N}$ & $\%$ \\
\hline With children & 14 & 12 \\
\hline Without children & 102 & 88 \\
\hline
\end{tabular}

\section{Statistical analysis}

We performed descriptive and inferential analysis of the evaluated variables. The statistical significance level for analysis was $p \leq .05$. The analyses were carried out using the statistical package SPSS 20.0 and QS 6.1. 


\section{Results}

\section{Information received about the possible loss of fertility associated with cancer treatment}

Various issues related to the information process were analysed. Regarding the source of information, $84.5 \%(\mathrm{~N}=98)$ of the sample obtained information about the possible loss of fertility due to cancer treatment from their oncologist or haematologist, $5.2 \%(\mathrm{~N}=6)$ were informed by the family doctor or general practitioner, $25.9 \%(\mathrm{~N}=30)$ got this information from a medical specialist (the most frequently mentioned were surgeons and gynaecologists), $8.6 \%(\mathrm{~N}=10)$ obtained this information from a family member, $6.9 \%(\mathrm{~N}=8)$ were informed by another patient and $12.9 \%$ of the sample $(\mathrm{N}=8)$ also received information about it through the media, such as magazines or internet. We emphasize these categories are not mutually exclusive, so a patient could have indicated more than one source of information. The degree of patients satisfaction with the information received was scored with an average of 7.66 out of 10 , but $41.4 \%(\mathrm{~N}=48)$ of the sample said that they would change the information they had received or the type of information received. Mainly those women would like to receive more information about side effects of cancer treatment and more time to discuss it, more explanations of all the options to preserve fertility, and more coordination between oncologist and gynaecologist, among others.

\section{Degree of concern about possible infertility Motivations and attitudes towards OTC}

Women rated the degree of concern about the effects of treatment on their reproductive capacity with a score of 8.09 over 10. Having cryopreserved their ovarian tissue decreased the level of concern in $97 \%(\mathrm{~N}=112)$ of the sample. Women showed high motivation in their choice of OTC, it was scored with a 9.4 over 10 . The main reasons to decide undergo OTC were having children and having the opportunity to decide in the future $(84.75 \%)$, ensure their fertility in the future $(6.11 \%)$ and not suffer an early menopause $(6.11 \%)$.

\section{Motivations and attitudes towards motherhood}

Women valued having children (8.66 out 10) and to restore hormone function (8.06 out 10) as very important. Considering the desire of having children in the future, $67.2 \%(\mathrm{~N}=78)$ of sample said to be sure that she wanted to have a child in the future, $28.4 \%(\mathrm{~N}=33)$ would probably want one and $4.3(\mathrm{~N}=5)$ was not sure. However, $30 \%$ $(\mathrm{N}=34)$ considered that having the disease and knowing the effect of the treatment on their fertility had increased their desire to have children, $66 \%(\mathrm{~N}=77)$ considered that it had not altered their desire of having children and $4 \%(\mathrm{~N}=5)$ felt that the disease had decreased their desire to have children. Thus, $28 \%(\mathrm{~N}=32)$ believed that women without children were not complete. As alternative ways to biological motherhood they had a more positive attitude towards adoption $(58 \%$ strongly agree) than to ovum donation ( $23 \%$ strongly agree).

\section{Levels of emotional distress, social support and coping strategies}

The descriptive results of these variables are shown in Table 2. The results of the BSI-18 indicated low levels of psychological distress. In fact, only 10 women ( $8.7 \%$ of the sample) obtained scores into the clinical range following the criteria of the instrument's author. ${ }^{47}$ The results of the EMASP reported high levels of social support perceived in the total scale and in the three subscales (family, friends and relevant persons), considering the range of possible scores on scales (67,98 out 72 in Total score and almost 23 out of 24 in the three subscales). The COPE showed that the coping strategies most used by women in our sample were Cognitive Coping, Search of Support and Active Coping; while the Humour and Religion scales were moderately employed and Alcohol and Drugs were the least used strategies.

Table 2 Descriptive datas of variables $(\mathrm{N}=116)$

\begin{tabular}{llll} 
BSI - I8 & Mean & S.D. & $\begin{array}{l}\text { Range of scale } \\
\text { Scores }\end{array}$ \\
\hline Global score & 8,86 & 8,92 & $0-72$ \\
Somatization & 1,60 & 2,79 & $0-24$ \\
Depression & 3,27 & 3,54 & $0-24$ \\
Anxiety & 3,99 & 3,87 & $0-24$ \\
EMASP & Mean & S.D. & $\begin{array}{l}\text { Range of scale } \\
\text { scores }\end{array}$ \\
Global score & 67,98 & 5,03 & Dec-72 \\
Family & 22,29 & 2,64 & $24-A p r$ \\
Friends & 22,84 & 2,84 & $24-A p r$ \\
Relevant people & 22,85 & 2,68 & $24-A p r$
\end{tabular}

\begin{tabular}{lllll} 
COPE & Mean & $\begin{array}{l}\text { Weighted } \\
\text { mean by } \\
\text { number of } \\
\text { items ( I-4) }\end{array}$ & S.D. & $\begin{array}{l}\text { Range of scale } \\
\text { scores }\end{array}$ \\
Support & 39.02 & 3.25 & 6.73 & $12-48$ \\
Active Coping & 35.6 & 2.97 & 7.04 & Dec-48 \\
Religion & 6.89 & 1.72 & 3.59 & $4-16$ \\
Cognitive Coping & 26.88 & 3.36 & 4.17 & Aug-32 \\
Humor & 7.53 & 1.88 & 3.54 & $4-16$ \\
Alcohol or drugs & 4.13 & 1.03 & 0.47 & $4-16$ \\
\hline
\end{tabular}

Relationships between emotional distress, social support and coping strategies used

After correlation analysis between all the psychological variables evaluated through standardized instruments we did regression analysis in order to determine which variables, specifically what coping strategies and level of perceived social support, play an important role in predicting emotional distress. Coping scales assessed by the COPE and social support assessed by the EMASP that had shown significant correlations with relevant criteria will be used as predictors in the regression analyses. Table 3 shows significant correlations and significant tends between all the variables and Table 4 the regression analysis realized. Considering the Global score of BSI-18 as dependent variable, the resulting function included as significant variables the scales of Search of Support $(\beta=.34)$ and Religion $(\beta=.22)$ of the COPE instrument, positively associated with emotional distress, and Overall Social Support Perceived (of the EMASP) $(\beta=-.29)$ and the Cognitive Coping scale of the COPE $(\beta=-.33)$ negatively associated with emotional distress. The variance explained by these variables was $30 \%$.

Also we made regression analysis for each subscale of the BSI-18 (somatization, depression and anxiety). In the case of Somatization subscale, regression function included as significant predictors the 
use of Religion as a positively associated coping strategy $(\beta=.16)$ and social support from Relevant People $(\beta=-.23)$ in the negative sense, and both predictors accounted $6 \%$ of the variance. In the case of regression analysis for Depression and Anxiety subscales of BSI18 , the same independent variables were included in the regression equation and the results of both regression analysis were also the same.
The independent variables in the equation were Global Social Support (EMASP) and Cognitive Coping (COPE) with negative association with dependent variable, and Religion and Search of Support coping strategies (COPE) with positive association. All these variables contributed significantly to the regression equation and explained the $36 \%$ of the variance for depression and the $25 \%$ in the case of anxiety.

Table 3 Correlations between the variables evaluated $(\mathrm{N}=116)$

\begin{tabular}{|c|c|c|c|c|c|c|c|c|c|c|c|c|c|c|}
\hline & 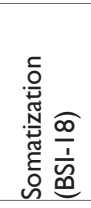 & 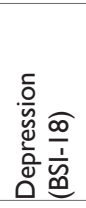 & $\begin{array}{l}\frac{0}{1} \\
\frac{1}{\sqrt{n}} \\
\frac{0}{d} \\
\frac{0}{x} \\
\frac{c}{<}\end{array}$ & 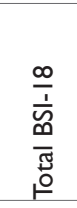 & 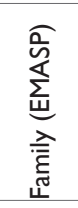 & 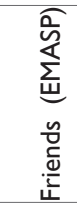 & 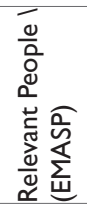 & $\begin{array}{l}\frac{0}{4} \\
\sum_{\amalg}^{4} \\
\frac{\pi}{0} \\
\stackrel{0}{0}\end{array}$ & 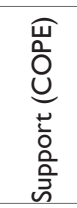 & 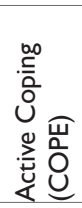 & 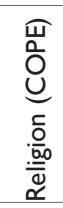 & 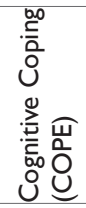 & 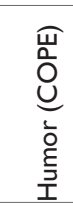 & $\begin{array}{l}\frac{1}{0} \\
0 \\
0 \\
\frac{0}{0} \\
\frac{0}{0} \\
\frac{u}{4}\end{array}$ \\
\hline Somatizatization (BSI-I8) & 1 & & & & & & & & & & & & & \\
\hline Depression (BSI- I8) & $0,47 * *$ & I & & & & & & & & & & & & \\
\hline Anxiety(BSI-I8) &, $67^{* *}$ &, $75^{* *}$ & I & & & & & & & & & & & \\
\hline Total BSI- 8 &, $79 * *$ &, $87 * *$ &, $94 * *$ & I & & & & & & & & & & \\
\hline Family (EMASP) & & & & & I & & & & & & & & & \\
\hline Friends (EMASP) & & -47 & $-0,2$ & $-0,29$ & & I & & & & & & & & \\
\hline Total EMASP & & $-0,37$ & $-0,23$ & $-0,29$ &, $70 * *$ &, $66 * *$ &, $59 * *$ & I & & & & & & \\
\hline Support (COPE) & &, $23^{*}$ &, $22 *$ &, $22 *$ & & & & & I & & & & & \\
\hline Active Coping (COPE) & & & & & & & & &, $59 * *$ & I & & & & \\
\hline Religion (COPE) &, $22^{*}$ &, $29 * *$ &, $32 * *$ &, $32^{* *}$ & & & & &, $21 *$ & & I & & & \\
\hline Cognitive Coping (COPE) & & $-0,31$ & $-0,25$ & $-0,29$ & &, 180 & &, $21 *$ &, $35 * *$ &, $35 * *$ & & I & & \\
\hline Humor (COPE) & & & & & & & & & & & & & I & \\
\hline Alcohol (COPE) & & & & & & & & & & & & & , 19* & I \\
\hline
\end{tabular}

**.Significant correlation at the level 0,0I (bilateral).

*.Significant correlation at the level 0,05 (bilateral).

Table 4 Regression analysis. Dependent variables: General Distress and subscales (BSI-18). Predictor variables: coping strategies (COPE) and social support (EMASP) $(\mathrm{N}=116)$

\begin{tabular}{|c|c|c|c|c|c|c|}
\hline Total BSI- I 8 & $\mathrm{R}^{2}=.33$ & $\mathrm{R}^{2} \mathrm{c}=.30$ & $F=\mid 3.29$ & $\mathrm{p}=.000$ & & \\
\hline & $\beta$ & & $\mathrm{t}$ & & $\mathrm{P}$ & \\
\hline \multicolumn{7}{|l|}{ Constant } \\
\hline Global Social Support Perceived (Total EMASP) & -0.29 & & -3.53 & & 0.001 & \\
\hline Search of Support (COPE) & 0.34 & & 3.89 & & 0 & \\
\hline Religion (COPE) & 0.22 & & 2.78 & & 0.006 & \\
\hline Cognitive Coping (COPE) & -0.33 & & -3.87 & & 0 & \\
\hline \multirow[t]{2}{*}{ Somatization (BSI- I8) } & $\mathrm{R}^{2}=.08$ & $\mathbf{R}^{2} \mathrm{c}=.06$ & $F=4.88$ & $\mathrm{p}=.009$ & & \\
\hline & & $\beta$ & & $\mathrm{t}$ & & $P$ \\
\hline Constant & & & & & & \\
\hline
\end{tabular}




\begin{tabular}{|c|c|c|c|c|c|}
\hline Relevant people (EMASP) & & -0.23 & & -0.02 & 0.05 \\
\hline Religion (COPE) & & 0.16 & & 2.33 & 0.02 \\
\hline \multirow[t]{2}{*}{ Depression (BSI- I8) } & $\mathbf{R}^{2}=.39$ & $\mathrm{R}^{2} \mathrm{c}=.36$ & $F=17.62$ & $p=.00$ & \\
\hline & & $\beta$ & & $\mathrm{t}$ & $P$ \\
\hline \multicolumn{6}{|l|}{ Constant } \\
\hline & & -0.36 & & -4.71 & 0 \\
\hline \multicolumn{6}{|l|}{ Global Social Support Perceived (Total EMASP) } \\
\hline Search of support (COPE) & & 0.33 & & 4.65 & 0 \\
\hline Cognitive Coping (COPE) & & -0.36 & & -4.36 & 0 \\
\hline Religion (COPE) & & 0.18 & & 2.32 & 0.02 \\
\hline \multirow[t]{2}{*}{ Anxiety (BSI- I8) } & $\mathrm{R}^{2}=.27$ & $\mathrm{R}^{2} \mathrm{c}=.25$ & $F=|0.3|$ & $p=.00$ & \\
\hline & & $\beta$ & & $\mathrm{t}$ & $P$ \\
\hline \multicolumn{6}{|l|}{ Constant } \\
\hline Global Social Support Perceived (Total EMASP) & & -0.23 & & -2.73 & 0.01 \\
\hline Search of Support (COPE) & & 0.32 & & 3.51 & 0 \\
\hline Cognitive Coping (COPE) & & -0.3 & & -3.34 & 0 \\
\hline Religion (COPE) & & 0.23 & & 2.77 & 0.01 \\
\hline
\end{tabular}

\section{Discussion}

Our study verifies that the possible loss of fertility is a great concern for young women diagnosed with cancer, coinciding with the results found in other studies. ${ }^{14-18}$ However, a large majority (97\%) of our sample said that undergoing OTC alleviated this concern. This result also coincides with those found in other studies, which concluded that to undergo techniques for fertility preservation has positive effects on the attitudes of patients coping with cancer. ${ }^{50-54}$ In fact, survivors of breast cancer who had preserved their fertility were much less concerned about their future fertility than those who had not preserved it. ${ }^{15}$ One of the advantages of cryopreservation of ovarian tissue compared to other alternatives for preserving fertility, is that not only allow having children but also can restore the hormonal ovarian function. Thus, among the main reasons why the women of our study decided to cryopreserve ovarian tissue was not only to be able to have children in the future but also not have an early menopause. In fact, when we evaluated separately the importance attached to have a child, and moreover, to restore hormonal function after treatment against cancer, we saw that both issues were very important for them and got high mean scores: $8.66(\mathrm{SD}=1.72)$ and $8.06(\mathrm{SD}=2.23)$ respectively. The cessation of hormone function is associated with vasomotor, skeletal, genitourinary and cardiovascular problems, and may be accompanied by specific symptoms such as hot flashes, vaginal dryness, sexual dysfunction, weight gain, psychological distress and possible cognitive impairment. ${ }^{55-58}$ In fact, there is evidence that young women, who because of their cancer diagnosis suffer early menopause, have shown a poorer quality of life and poorer health perception. ${ }^{9,59}$ This could explain why women in our study gave importance to this issue.

The degree of concern that caused knowing the possible loss of fertility due to treatment of cancer, has been particularly associated with the desire to have children in the future and having children or not at the time of diagnosis. . $7,23,45,60,61$ In our work we assessed the desire to have children in the future and this was high. However, the results of several studies suggested that this desire to become a mother is not affected by the diagnosis of cancer, and again the results of our study are consistent with these data. ${ }^{10,45,46}$ As an alternative to biological maternity, patients in our study showed a more favorable attitude towards adoption than to ovum donation. These results are in line with those found by other authors who have also seen a positive attitude towards adoption and preference for this alternative compared to donor eggs or sperm. ${ }^{8,12,23,45}$

Moreover, studies agree that is very important for cancer patients to receive information about both, the possible impairment of reproductive capacity and early menopause, and this information is considered more important in the case of those younger women without children at the time of diagnosis and with plans to have children in the future ${ }^{61-64}$ In our study we have seen that is the oncologist who usually informs about this, coinciding with those reported in other studies. ${ }^{15,45,60,61,65}$ The women of our sample are quite satisfied with the information received. However, $41.1 \%(\mathrm{~N}=48)$ of the sample said they would change the mode and type of information they had received 
and they suggested, between others, spend more time providing detailed information in this topic as well as about the intervention of OTC, and they also proposed that cancer services should be more informed about this effect and the options for preserving fertility and a higher coordination between oncologists and gynaecologists. These suggestions go in the same line as several published studies. In fact, the study of Corney et al. ${ }^{16}$ also contains suggestions of patients in their sample and mostly coincided with those of our patients. In the study of Green, Galvan et al..$^{39}$ a high percentage of their sample felt that the information they had received was poor. Something similar was found in the study of Schover et al. ${ }^{46}$ where the limited information was a reason for not having preserved and the study of Thewes et al. ${ }^{62}$ concluded that it was necessary to improve information to young women with breast cancer on this topic.

There seems to be some consensus in the psychological impact on young women who have been treated for an oncological disease and as a result they have reproductive problems. Carter et al. ${ }^{12}$ concluded in their study that women with a history of gynaecological cancer who had lost their reproductive capacity had symptoms of depression, sadness and stress. Specifically $44 \%$ of their sample had clinical criteria for depression, and $35 \%$ had moderate to severe levels of psychological distress. A few years later, these same authors, with a larger sample of women also with a history of gynaecological cancer Carter et al. ${ }^{14}$ found that $77 \%$ obtained clinically significant scores of distress due to the loss of their fertility and 6\% scores indicating clinical depression. More recently, Penrose et al. ${ }^{19}$ with a sample of cancer survivors, found that $56 \%$ reported being concerned about this issue and said they had expressed strong emotional reactions to know that side effects and $20 \%$ reported having experienced distress.

In our study we evaluated, through standardized instruments, the level of psychological distress by the possible loss of fertility and its relationship with coping strategies and perceived social support. The scores obtained by our sample were low in the Global score of emotional distress and in the three subscales: somatization, depression and anxiety. Our results do not agree with those found in other studies but other results of our study can explain this difference. So, in our study we found that those variables which were associated with increased symptoms of emotional distress were the increased use of coping strategies such as Search of Support and Religion combined with low use of Cognitive coping strategies and low Perceived Social Support. The fact that our sample presented high scores in social support and the coping strategies more employed were essentially active and problem-focused may contribute to the low level of emotional distress manifested, since both variables were associated with better psychological adjustment in cancer patients in general and in specific samples of young women with infertility due to cancer treatment. ${ }^{10,37,38}$ Also, the specific characteristics of our sample (high sociocultural level and having preserved fertility), may be contributing to the low levels of emotional distress.

\section{Conclusion}

The possible loss of fertility concerns young women newly diagnosed with cancer. However the level of emotional distress experienced is not clinically significant. Having cryopreserved ovarian tissue alleviates the level of concern and it has positive effects on their attitudes to the disease. It is important to emphasize the exploratory character of our study and the need to get new investigations in this area. Despite this and the limitations associated with the characteristics of our sample, we believe that through our results we have achieved to understand a little better the attitudes of our patients to this fact.

\section{Acknowledgments}

None.

\section{Conflicts of interest}

The author declares there is no conflict of interest.

\section{References}

1. Altekruse SF, Kosary CL, Krapcho M. et al. SEER cancer statistics review, 1975-2007. In: Bethesda editor. 2010.

2. Bahadur G. Fertility issues for cancer patients. Molecular and Cellular Endocrinology 2000;169(1-2):117-122.

3. Cousineau TM, Domar AD. Psychological impact of infertility. Best Practice \& Research Clinical Obstetrics and Gynaecology. 2007;21(2):293-308.

4. Greil AL, Slauson-Blevins K, McQuillan J. The experience of infertility: a review of recent literature. Sociology of Health \& Illness. 2010;32(1):140-162.

5. Wischmann T, Schiling K, Toth B, et al. Sexuality, Self-Esteem and Partnership Quality in Infertilie Women and Men. Geburtshilfe und Frauenheilkunde. 2014;74(8):759-763.

6. Cwikel J, Gidron Y, Sheiner. Psychological interactions with infertility among women. European Journal of Obstetrics \& Gynecology and Reproductive Biology. 2004;117(2):126-131

7. Domar AD, Zuttermeister PC, Seibel M, et al. Psychological improvement in infertile women after behavioral treatment: a replication. Fertility and Sterility. 1992:58(1):144-147.

8. Schover LR. Psychosocial aspects of infertility and decisions about reproduction in young cancer survivors: a review. Medical and Pediatric Oncology. 1999;33(1):53-59.

9. Bisseling KCHM, Kondalsamy -Chennakesavan S, Bekkers RLM, et al. Depression, anxiety and body image after treatment for invasive stage one epithelial ovarian cancer. Australian and New Zealand Journal of Obstetrics and Gynaecology. 2009;49(6):660-666.

10. Canada AL, Schover LR. The psychosocial impact of interrupted childbearing in long-term female cancer survivors. Psycho-Oncology. 2012;21(2):134-143.

11. Carter J, Rowland K, Dennis Ch, et al. Ginecologic cancer treatment and the impact of cancer-related infertility. Gynecologic Oncology. 2005;97(1):90-95

12. Carter J, Chi DS, Brown CL, et al. Cancer-Related Infertility in Survivorship. International Journal of Gynecological Cancer. 2010(a);20(1):2-8

13. Carter J, Raviv L, Applegarth L, et al. A cross-sectional study of the psychosexual impact of cancer-related infertility in women: third-party reproductive assistance. Journal of Cancer Survivors. 2010;4(3):236246

14. Crawshaw MA, Sloper P. 'Swimming against the tide'- the influence of fertility matters on the transition to adulthood or survivorship following adolescent cancer. European Journal of Cancer Care. 2010;19(5):610620 .

15. Corney RH, Swinglehurst AJ. Young childless women with breast cancer in the UK: a qualitative study of their fertility-related experiences, options, and the information given by health professionals. PsychoOncology. 2014;23(1):20-26. 
16. Kondapalli LA, Dillon KE, Sammel MD, et al. Quality of life in female cancer survivors: is it related to ovarian reserve? Quality of Life Research. 2014;23(2):585-592.

17. Partridge AH, Gelber S, Peppercorn J, et al. Web-Based survey of fertility issues in young women with breast cancer. Journal of Clinical Oncology. 2004;22 (20):4174-4183.

18. Penrose R, Beatty L, Mattiske J, et al. Fertlity and cancer qualitative study of Australian cancer survivors. Support Care Cancer. 2012;20(6):1259-1265.

19. Ruddy KJ, Gelber S, Ginsburg ES, et al. Menopausal symptoms and fertility concerns in premenopausal breast cancer survivors: a comparison to age- and gravidity- matched controls. Menopause. 2011;18(1):105-108.

20. Wenzel L, Dogan-Ates A, Habbal R, et al. Defining and measuring reproductive concerns of female cancer survivors. Journal of the National Cancer Institute Monographs. 2005;34:94-98.

21. Gonçalves V, Sehovic I, Quinn G. Childbearing attitudes and decisions of young breast cancer survivors: a systematic review. Human Reproduction Update. 2014;20(2):279-292.

22. Mosher CE, Duhamel KN, Rini C, et al. Quality of life concerns and depression among hematopoietic stem cell transplant survivors. Support Care Cancer. 2011;19(9):1357-1365.

23. Hammond C, Abrams JR, Syrjala DL. Fertility and Risk Factors for Elevated Infertility Concern in 10-Year Hematopietic Cell Transplant Survivors and Case-Matched Controls. Journal of Clinical Oncology. 2007;25(23):3511-3517.

24. Donnez J, Dolmans MM, Demylle D, et al. Livebirth alter orthotopic transplantation of cryopreserved ovarian tissue. Lancet. 2004;364(9443):1405-1410.

25. Donnez J, Godin PA, Qu J, et al. Gonadal cryopreservation in the young patient with gynaecological malignancy. Current Opinion in Obstetrics and Gynecology. 2000;12(1):1-9.

26. Donnez J, Jadoul P, Squifflet J, et al. Ovarian tissue cryopreservation and transplantation in cancer patients. Best Practice \& Research. Clinical Obstetrics \& Gynaecology. 2010;24(1):87-100.

27. Gosden RG. Prospects for oocyte banding and in vitro maturation. Journal of the National Cancer Institute Monographs.2005;34:60-63.

28. Gosden RG, Rutherford AJ, Norfolk DR. Ovarian banking for cancer patients: transmission of malignant cells in ovarian grafts. Human Reproduction. 1997;12:403-405.

29. Kim SS, Donnez J, Barri P, et al. Recommendations for fertility preservation in patients with lymphoma, leukemia, and breast cancer. Journal of Assisted Reproduction and Genetics. 2012;29(6):465-468.

30. Kim SS, Hwang IT, Lee HC. Heterotopic autotrasplantation of cryobanked human ovarian tissue as a strategy to restore ovarian function. Fertility and Sterility. 2004;82(4):930-932.

31. Lobo RA. Potential options for preservation of fertility in women. The New England Journal of Medicine. 2005;353(1):64-73.

32. Loren AW, Mangu PB, Beck LN, et al. Fertility Preservation for Patients With Cancer: American Society of Clinical Oncology Clinical Practice Guideline Update. Journal of Clinical Oncology. 2013;31(19):25002510 .

33. Meirow D, Levron J, Eldar-Geva T, et al. Pregnancy after transplantation of cryopreserved ovarian tissue in a patient with ovarian failure after chemotherapy. The New England Journal of Medicine. 2005;353(3):318321.
34. Oktay K, Karlikaya G. Ovarian function after transplantation of frozen, banked autologous ovarian tissue. The New England Jorunal of Medicine. 2000;342(25):1919.

35. Torrents E, Boiso I, Barri PN, et al. Applications of ovarian tissue transplantation in experimental biology and medicine. Human Reproduction Update. 2003;9(5):471-481.

36. Hack TF, Degner LF. Coping with breast cancer: A cluster analytic approach. Breast Cancer Research and Treatment. 1999;54(3):185-194.

37. Lafaye A, Petit S, Richaud P, et al. Dyadic effects of coping strategies on emotional state and quality of life in prostate cancer patients and their spouses. Psycho-Oncology. 2014;23(7):797-803.

38. Llewellyn CD, Horney DJ, McGurk M, et al. Assessing the psychological predictors of benefit finding in patients with head and neck cancer. Psycho-Oncology. 2013;22(1):97-105.

39. McCaul KD, Sandgren AK, King B, et al. Coping and adjustement to breast cancer. Psychooncology. 1999;8(8):230-236.

40. Wang Y, Zhu X, Yang Y, et al. What factors are predictive of benefit finding in women treated for non-metastatic breast cancer? A prospective study. Psychooncology. 2014;24(5):533-539.

41. Gibson DM, Myers JE. The effect of social coping resources and growth-fostering relationships on infertility stress in women. Journal of Mental Health Counseling. 2002;2:68-80.

42. Rockliff HE, Lightman SL, Rhidian E, et al. A systematic review of psychosocial factors associated with emotional adjustment in in vitro fertilization patients. Human Reproduction. 2014;20(4):594-613.

43. Schmidt L, Christensen U, Holstein BE. The social epidemiology of coping with infertility. Human Reproduction. 2005;20(4):1044-1052.

44. Schmidt L, Holstein BE, Christensen U, et al. Communication and coping as predictors of fertility problem stress: cohort study of 816 participants who did not achieve a delivery after 12 months of fertility treatment. Human Reproduction. 2005;20(11):3248-3256.

45. Schover LR, Brey K, Lichtin A, et al. Knowledge and experience regarding cancer, infertility, and sperm banking in younger male survivors. Journal of Clinical Oncology. 2002;20(7):1880-1890.

46. Zanagnolo V, Sartori E, Trussardi E, et al. Preservation of ovarian function, reproductive ability and emotional attitudes in patients with malignant ovarian tumors. European Journal of Obstetrics \& Gynecology and Reproductive Biology. 2005;123(2):235-243.

47. Derogatis LR. Brief Symptom Inventory (BSI). Administration, Scoring and Procedures Manual $3^{\text {rd }}$ ed. Minneapolis: NCs Pearson, Inc. 1993. p. 1-13.

48. Landeta O, Calvete E. Adaptación y validación de la Escala Multidimensional de Apoyo Social Percibido. Ansiedad y Estrés. 2002;8(2-3):173-182.

49. Carver CS, Scheier MF, Weintraub JK. Assesing Coping Strategies: A Theoretically Based Approach. Journal of Personality and Social Psychology. 1989;56(2):267-283.

50. Gardino SL, Emmanuel LL. Choosing Life When Facing Death: Understanding Fertility Preservation Decisión-Making for Cancer Patients. Cancer Treatment and Research. 2010;156:447-458.

51. Ginsberg JP, Ogle SK, Tuchman LK, et al. Sperm banking for adolescent and young adult cancer patients: Sperm quality, patient and parent perspectives. Pediatric Blood \& Cancer. 2008;50:594-598.

52. Hammer Burns L, Covington S. Infertility Counseling: A Comprehensive Handbook for Clinicians, $2^{\text {nd }}$ ed. New York: Cambridge University Press. 2000. p. 1-680. 
53. Saito K, Suzuki K, Iwasaki A, et al. Sperm cryopreservation before cancer chemotherapy helps in the emotional battle against cancer. Cancer. 2005;104(3):521-524.

54. Schover LR, Jenkins R, Sui D, et al. Randomized Trial of Peer Counselling on Reproductive Health in African American Breast Cancer Survivors. J Clinical Oncology. 2006;24(10):1620-1626.

55. Bender C, Paraska K, Sereika S, et al. Cognitive function and reproductive hormones in adjuvant therapy for breast cancer: A critical review. Journal of Pain and Symptom Management. 2001;21(5):407424.

56. Ganz PA, Rowland JH, Desmond K, et al. Life after breast cancer: understanding women's health-related quality of life and sexual functioning. Journal of Clinical Oncology. 1998;16(2):501-514.

57. Goodwin P, Ennis M, Pritchard K, et al. Risk of menopause during the first year after breast cancer diagnosis. Journal of Clinical Oncology. 1999; 17(8):2365-2370.

58. Moore H. Managing menopause after breast cancer: Balancing risks and benefits. Cleveland Clinic Journal of Medicine. 2001;68(3):243-248.

59. Shapiro CL, Manola J, Leboff M. Ovarian Failure After Adjuvant Chemotherapy Is Associated With Rapid Bone Loss in Women With Early-Stage Breast Cancer. Journal of Clinical Oncology. 2001;19(14):3306-3311.
60. Duffy CM, Allen SM, Clark MA. Discussions regarding reproductive health for young women with breast cancer undergoing chemotherapy. Journal of Clinical Oncology. 2005;23(4):766-773.

61. Thewes B, Meiser A, Taylor KA, et al. Fertility- and Menopause-Related Information Needs of Younger Women with a Diagnosis of Early Breast Cancer. J Clin Oncol. 2005;23(22):5155-5165.

62. Huyghe E, Martinetti P, Sui D, et al. Banking on fatherhood: pilot studies of a computerized educational tool on sperm banking before cancer treatment. Psycho-Oncology. 2009;18(9):1011-1014.

63. Nakayama K, Liu P, Detry $M$, et al. Receiving Information on Fertility and Menopause Related Treatment Effects among Women Who Undergo Hematopoietic Stem Cell Transplantation: Changes in Perceived Importance Over Time. Biol of Blood Marrow Transplant. 2009;15(11):1465-1474.

64. Zebrack B. Information and service needs for young adult cancer patients. Support Care Cancer. 2008;16(12):1353-1360.

65. Crawshaw MA, Glaser AW, Hale JP, et al. Male and female experiences of having fertility matters raised alongside a cancer diagnosis during the teenage and young adult years. European Journal of Cancer Care. 2009;18(4):381-390. 